\title{
SARS-CoV-2 infection drives a glycan switch of peripheral $T$ cells at diagnosis.
}

Inês Alves ${ }^{1,2,3 \$}$, Manuel M. Vicente ${ }^{1,2,4 \$}$; Joana Gaifem ${ }^{1,2}$, Ângela Fernandes ${ }^{1,2}$, Ana M. Dias ${ }^{1,2}$, Cláudia S. Rodrigues ${ }^{1,2}$, José Carlos Oliveira ${ }^{5}$, Nair Seixas ${ }^{6}$, Luis Malheiro ${ }^{7}$, Miguel A. Abreu ${ }^{4,8}$; Rui Sarmento e Castro ${ }^{4,8}$; Salomé S. Pinho ${ }^{1,2,3,4,9^{*}}$

\footnotetext{
${ }^{1}$ Institute of Molecular Pathology and Immunology, University of Porto (IPATIMUP), 4200-135 Porto, Portugal

${ }^{2}$ i3S - Institute for Research and Innovation in Health, University of Porto, 4200-135 Porto, Portugal.

${ }^{3}$ Faculty of Medicine, University of Porto, 4200-319 Porto, Portugal.

${ }^{4}$ Institute of Biomedical Sciences Abel Salazar (ICBAS), University of Porto, 4050-313 Porto, Portugal.

${ }^{5}$ Department of Clinical Pathology, Centro Hospitalar Universitário do Porto, 4099-001 Porto, Portugal.

${ }^{6}$ Department of Clinical Pathology, Centro Hospitalar Vila Nova de Gaia/Espinho, 4434-502 Gaia, Portugal

${ }^{7}$ Department of Infectious Diseases, Centro Hospitalar Vila Nova de Gaia/Espinho, 4434-502 Gaia, Portugal

${ }^{8}$ Department of Infectious Diseases, Centro Hospitalar Universitário do Porto, 4099-001 Porto, Portugal.

${ }^{9}$ Lead Contact

\$These authors contributed equally

*Corresponding author: salomep@ipatimup.pt (S.S.P)
}

Grant Support: The Institute of Molecular Pathology and Immunology of the University of Porto integrates the Institute for Research and Innovation in Health (i3S) research unit, which is partially supported by the Portuguese Foundation for Science and Technology (FCT). This article was partially funded by the FCT, in collaboration with the Portuguese Agency for Clinical Research and Biomedical Innovation (AICIB) under the special funding, "RESEARCH 4 COVID-19"_Project \#006 granted to the PI Salomé S. Pinho. IA [SFRH/BD/128874/2017] and MV [PD/BD/135452/2017] received funding from the FCT.

Running Title: $\mathrm{T}$ cell glycan switch in SARS-CoV-2 infection

\section{Abstract}

COVID-19 is a highly selective disease in which SARS-CoV-2 infection can result in different clinical manifestations ranging from asymptomatic/mild to severe disease that requires hospitalization. Here, we demonstrated that SARS-CoV-2 infection results in a glycosylation reprogramming of circulating lymphocytes at diagnosis. We identified a specific glycosignature of T cells, defined upon SARS-CoV-2 infection and apparently triggered by a serological factor. This specific glycan switch of $\mathrm{T}$ cells is detected at diagnosis being more pronounced in asymptomatic patients. We further demonstrated that asymptomatic patients display an increased expression of a viral-sensing receptor, through the up-regulation of DC-SIGN in monocytes. We showed that higher levels of DC-SIGN in monocytes at diagnosis correlates with better COVID-19 prognosis. These NOTE: This preprint reports new ressearch that has not been certified by peer eview and should not be used to guide clinical practice. new evidences pave the way to the identification of a novel glycan-based response in $T$ 
medRxiv preprint doi: https://doi.org/10.1101/2021.02.17.21251918; this version posted February 22,2021 . The copyright holder for this preprint (which was not certified by peer review) is the author/funder, who has granted medRxiv a license to display the preprint in

39

40

cells that may confer protection against SARS-CoV-2 infection in asymptomatic patients, highlighting a novel prognostic biomarker and potential therapeutic target.

Keywords: asymptomatic / DC-SIGN / glycan-recognition receptors / $N$-glycosylation / prognosis / SARS-CoV-2 / T-cell activation

\section{Introduction}

Coronavirus SARS-CoV-2 is the etiologic agent responsible for the global pandemic of Coronavirus disease 2019 (COVID-19), that, as of $9^{\text {th }}$ of February, has infected over 106 million people worldwide(1,2). The overall mortality of COVID-19 is between $0.5 \%$ and $3.5 \%(1,2)$. COVID-19 is a highly selective disease. In fact, only some infected individuals get sick, and although most of the critically ill are elderly, some patients that die are previously healthy and/or relatively young(3). There is an urgent need to improve the understanding of the pathophysiology of this disease, envisioning better management in terms of patients care, treatment options, vaccination strategies and the allocation of healthcare resources. Vaccine development against SARS-CoV-2 poses a great promise for the resolution of the pandemic, and several vaccines are now being distributed among the world population, namely mRNA- and protein-based approaches(4, 5). However, its long-term protection, effectiveness to re-infection, efficacy to new variants and availability for the general public is still on trial. This lack of knowledge highlights the importance of understanding patient-specific immune response to infection, envisioning the identification of novel mechanisms of disease. Moreover, comprehensive insights on COVID-19 molecular mechanism may be translated into diagnostic or prognostic biomarkers, therapeutic targets to improve patient's clinical management and patients's stratification for vaccination.

SARS-CoV-2 infection results in a broad range of symptoms(6). Several studies on immune profiling of infected patients consistently revealed an immunological dysregulation, observed in peripheral blood mononuclear cells (PBMCs). A decrease of $\mathrm{T}$ cells and dendritic cells frequencies and an increase of monocytes and neutrophils have been observed in hospitalized infected individuals, as well as a cytokine dysregulation, the so-called "cytokine storm" associated with critical illness(7-10). 
medRxiv preprint doi: https://doi.org/10.1101/2021.02.17.21251918; this version posted February 22,2021 . The copyright holder for this preprint (which was not certified by peer review) is the author/funder, who has granted medRxiv a license to display the preprint in

All rights reserved. No reuse allowed without permission.

However the mechanism underlying this immunological dysregulation remains largely unknown.

Despite overlooked, the field of glycobiology can provide missing answers to immunological questions. Glycosylation is a major post-translational mechanism characterized by the enzymatic addition of glycans (carbohydrates) to proteins or lipids of essentially all cells, including immune cells. In fact, glycans are master regulators of immune cell functions, defining the activation and differentiation of $\mathrm{T}$ cells $(11,12)$. In the cellular immune system, we and others have previously demonstrated the regulatory power of glycans in adaptive immune response through the modulation of $\mathrm{T}$ cell activation thresholds associated with the immunopathogenesis of autoimmune diseases and cancer(13-19). Moreover, being present in several pathogens, glycans can also be sensed by immune cells, through their recognition by specific glycan-recognizing receptors expressed in those cells(20). Like the majority of viruses, SARS-CoV-2 viral capsids are also covered with glycans. More specifically, the spike protein of the SARSCoV-2 envelope was shown to be highly glycosylated (harboring $22 \mathrm{~N}$-glycosylation sites) with glycan structures such as oligomannose and some branched $N$-glycans(21, 22). These structures can be specifically recognized by glycan binding proteins (GBPs) of host's immune cells, such as the C-type-lectin Dendritic Cell-Specific Intercellular adhesion molecule-3-Grabbing Non-integrin (DC-SIGN), present in innate immune cells, promoting virus recognition and elimination $(23,24)$.

Defining the glycosylation profiles of immune cells in SARS-CoV-2 infected individuals and how they impact their effector functions remains completely unknown, being of utmost importance for the understanding of COVID-19 immunopathogenesis, as well as for the improvement of the clinical management of the disease and for pandemic control measures, namely as a stratification biomarker.

In this study, we discovered that circulating T cells exhibit a glycan switch upon SARSCoV-2 infection that is detected at COVID-19 diagnosis. This change in the glycosylation profile of $\mathrm{T}$ cells appears to be triggered by a serum inflammatory factor present in infected patients. This specific $\mathrm{T}$ cell glycan switch is more pronounced in asymptomatic patients, rather than in those who exhibit symptoms. Importantly from a clinical standpoint, we also unveiled that COVID-19 patients with good prognosis exhibit an upregulation of DC-SIGN expression in circulating monocytes. 
medRxiv preprint doi: https://doi.org/10.1101/2021.02.17.21251918; this version posted February 22,2021 . The copyright holder for this preprint (which was not certified by peer review) is the author/funder, who has granted medRxiv a license to display the preprint in

All rights reserved. No reuse allowed without permission.

\section{Material and Methods}

\section{Cohort description and patient's selection criteria}

The present study integrates a total of 32 patients diagnosed with SARS-CoV-2 from 2 individual Portuguese cohorts (between May 2020 and July 2020), 20 patients from Infectious Disease Department, Centro Hospitalar e Universitário do Porto (CHUP), Porto, Portugal and 12 patients from Infectious Disease Department, Centro Hospitalar de Vila Nova de Gaia/Espinho (CHVNG), Vila Nova de Gaia, Portugal. The total cohort includes patients of both genders and age between 22 and 89 years old. All the samples were included in all the FACS analysis discussed.

Blood was collected and plasma and PBMCs were isolated at the time of diagnosis and 14 days $(n=6)$ after diagnosis. Similar analysis was conducted in a subset of patients $(n=2)$ that recovered.

The eligibility criteria for inclusion in this study were SARS-CoV-2 positive patients asymptomatic or symptomatic with different levels of severity (mild, moderate and severe). Asymptomatic patients $(n=5)$ were defined as positive for the SARS-CoV2 PCR test, but no signs of diseases. The following criteria were used to stratify symptomatic SARS-CoV-2 patients in terms of the disease severity and accordingly with WHO guidelines (25); 1- MILD $(n=18)$ : individuals with no evidences of pneumonia; 2- MODERATE $(n=6)$ : individuals without need of invasive mechanical ventilation and without need of admission to hospital intensive care unit, but evidence of pneumonia and need of supplemental oxygen; 3- SEVERE $(n=1)$ : individuals with need of invasive mechanical ventilation and with need of admission to hospital intensive care unit. Patients demographic and relevant clinical data are summarized in table 1 .

Healthy controls $(n=5)$ are represented by volunteer individuals with no history of infection disorders that underwent CHUP for routine analysis.

All participants gave informed consent about all clinical procedures and research protocols were approved by the ethics committee of CHUP and CHVNG, Portugal. 
medRxiv preprint doi: https://doi.org/10.1101/2021.02.17.21251918; this version posted February 22,2021 . The copyright holder for this preprint (which was not certified by peer review) is the author/funder, who has granted medRxiv a license to display the preprint in

All rights reserved. No reuse allowed without permission.

Human peripheral blood mononuclear cells (PBMCs) from COVID-19 patients and healthy donors were isolated by gradient centrifugation using 1 volume of Lymphoprep $^{\mathrm{TM}}$ (Stemcell Technologies) for 2 volumes of blood, 30 minutes at $900 \mathrm{x} g$ with the brake off. The upper phase, containing the serum, was collected and stored at $80^{\circ} \mathrm{C}$. PBMCs (interphase) were collected, washed twice with PBS and incubated with FVD-APC-eFluor780 (eBioscience) for 30 minutes. Cells were washed with PBS, fixed with 2\% formaldehyde (PanReac ApplieChem) and resuspended in FACS buffer (PBS 2\%FBS). All procedures were performed under biosafety level 3 (BSL3) conditions.

\section{Flow Cytometry Staining}

For lectin staining, cells were incubated with conjugated lectins (Vector Laboratories): Phaseolus Vulgaris leucoagglutinin (L-PHA-fluorescein, FITC), Galanthus Nivalis lectin (GNA-fluorescein, FITC), biotinylated Sambucus Nigra lectin (SNA) and biotinylated Aleuria aurantia lectin (AAL) for 15 minutes. Biotinylated lectins were incubated with streptavidin-PE-Cy7 (eBioscience) for 30 minutes. For surface marker staining, cells were stained for 30 minutes on ice while protected from light with the following antibodies: APC anti-human TCR $\gamma \delta$ (clone B1), BV510 antihuman CD69 (clone FN50), PE anti-human CD25 (clone BC96), BV421 anti-human CD14 (clone 63D3), PE anti-human CD56 (clone HCD56), PE-Cy7 anti-human CD206 (clone 15-2) from Biolegend; eFluor ${ }^{\mathrm{TM}} 450$ anti-human CD4 (clone RPA-T4), PerCPeFluor $^{\mathrm{TM}} 710$ anti-human PD-1 (clone J105), PE-Cy5 anti-human CD19 (clone HIB19), eFluor $^{\text {TM }} 450$ anti-human IgM (clone SA-DA4), eFluor ${ }^{\mathrm{TM}} 660$ anti-human galectin 3 (clone M3/38), APC anti-human CD11c (clone BU15), PE-Cy5 anti-human CD86 (clone IT2.2) from eBioscience; PE anti-human TCR $\alpha / \beta$ (clone BW242/412) from Miltenyi; BV510 anti-human CD3 (clone OKT3) from BD Biosciences; for DC-SIGN staining, cells were incubated with DC-SIGN rabbit IgG (Biorad) followed by incubation with polyclonal swine anti-rabbit IgG (FITC; Dako) for 30 minutes on ice. Cells were resuspended in FACS buffer prior analysis. Data were obtained on a BD FACS Canto II instrument (Becton Dickinson) and analyzed using FlowJo v10.0 (Tree Star Inc.).

\section{In vitro assessment of glycan modulation of $\mathrm{T}$ cells}

PBMCs from healthy and independent from the COVID-19 cohirt human donors were isolated from fresh collected blood, as described above. PBMCs were cultured in 
medRxiv preprint doi: https://doi.org/10.1101/2021.02.17.21251918; this version posted February 22,2021 . The copyright holder for this preprint (which was not certified by peer review) is the author/funder, who has granted medRxiv a license to display the preprint in

RPMI-1640 (Gibco) supplemented with 10\% (v/v) heat-inactivated fetal bovine serum, $1 \%$ penicillin/streptomycin and $10 \%$ of plasma from 4 asymptomatic or moderate patients, for each condition. Different cell culture conditions were tested, namely human plasma concentration (25\% and $10 \%$ ) as well as time of culture (4 days, 2 days, $24 \mathrm{~h}$ and 12h). The optimal culture condition (with lower cell death and stronger glycan modulation) was selected (10\% human plasma and $24 \mathrm{~h}$ cell culture). After $24 \mathrm{~h}$ cell glycoprofile was evaluated using the same antibodies and lectin panel selected above. Data were obtained on a BD FACS Canto II instrument (Becton Dickinson) and analyzed using the FlowJo 10.0 software (Tree Star Inc.).

\section{Data visualization and statistical analysis}

Data visualization and statistical analyses (non-parametric Mann-Whitney t-test) were done using GraphPad Prism 9 software.

The prediction capacity of DC-SIGN levels to discriminate patients who develop a poor disease course from those that have a good disease course was determined by plotting the receiver operating characteristic (ROC) curves and calculating the area under the curve (AUC). The cut-off that revealed the best balance between sensitivity and specificity was selected for the subsequent statistical analysis. Sensitivity, specificity, and positive and negative predictive values were calculated. Univariate binary logistic regression analysis was performed to test DC-SIGN levels and disease progression (good: asymptomatic maintained asymptomatic and/or severity decreased at least one category; poor: symptoms were not improved and/or escalate to a higher severity). In logistic regression, model goodness-of-fit was assessed by the HosmerLemeshow statistic and test. Results are presented as odds ratios (ORs) for each category as compared with a predefined reference category, and their respective $95 \%$ confidence intervals (CIs). Odds ratios above one and below one are indicative, respectively, of higher and lower odds of develop poor disease course as compared with a reference category. Statistical analysis was performed using the statistical software SPSS version 25 (IBM Corp., IBM SPSS Statistics for Windows, Version 25.0, Armonk, NY; released 2017) The threshold used for statistical significance was $p$ value $<0.05$. 
medRxiv preprint doi: https://doi.org/10.1101/2021.02.17.21251918; this version posted February 22,2021 . The copyright holder for this preprint (which was not certified by peer review) is the author/funder, who has granted medRxiv a license to display the preprint in

All rights reserved. No reuse allowed without permission.

195

196

197

198

199

200

201

202

203

204

205

206

207

208

209

210

211

212

213

214

215

216

217

218

219

220

221

222

223

224

225

\section{Results}

SARS-CoV-2 infected individuals display decreased $\beta 1,6-G l c N A c$ branched and $\alpha 2,6$-sialic acid $N$-glycans on peripheral $T$ cells at diagnosis.

Taking into consideration the fact that it is still unclear the underlying mechanisms that explain a differential inter-individual clinical presentation of COVID-19 at diagnosis, we herein characterized the glycosylation profile of $\mathrm{T}$ cells from patients' peripheral blood. A lectin-based flow cytometry of the $\mathrm{T}$ cell populations was performed to evaluate glycosylation profiles. We started by analysing the levels of expression of B1,6-GlcNAc branched $N$-glycan structures, known to have a major impact on the regulation of $\mathrm{T}$ cell activity and function(13, 16, 26), using the L-PHA lectin. Our results demonstrated that, overall, $\mathrm{T}$ cells from infected (IF) subjects have a decrease in branched $N$-glycan structures, particularly on $\mathrm{CD}^{+}$and $\gamma \delta \mathrm{T}$ cells, when compared to non-infected (non-IF) ones (Figure 1A, top and bottom left panel). Moreover, T cells from asymptomatic patients have lower levels of $\beta 1,6-$ GlcNAc branched $N$-glycans, that gradually tend to increase along disease severity (Figure 1A, right). Notably, $\mathrm{CD}^{+} \mathrm{T}$ cells display a significant decrease in the levels of expression of complex branched $\mathrm{N}$ glycans in asymptomatic and mild disease patients, when compared to non-IF individuals (Figure 1A, top).

Concerning $\alpha 2,6$-sialylation (recognized by the SNA lectin), already described to play a role in the regulation of $\mathrm{T}$ cells immune response(27), our results demonstrate that $\mathrm{CD}^{+} \mathrm{T}$ cells from IF patients display a significant decreased SNA binding, in comparison with non-IF individuals (Figure 1B, top left). Consistently, asymptomatic patients present the lowest levels of SNA binding compared to non-IF (Fig.1B, top right). Even though the levels of SNA binding were shown to be associated with age (Supplemental Figure 1E), there are no significant differences between the mean age of asymptomatic and symptomatic patients (Supplemental Table 1). Curiously, for both glycans, the two COVID-19 convalescent patients seem to recover (or surpass) the levels of expression of $\beta 1,6-$ GlcNAc branched and $\alpha 2,6$-sialic acid glycan structures in all $\mathrm{T}$ cell subsets (Fig. 1A and B, right). These results showed that $\mathrm{CD} 8^{+} \mathrm{T}$ cells from asymptomatic patients display a defect in branched and sialylated $N$-glycans when compared with non-IF. 
medRxiv preprint doi: https://doi.org/10.1101/2021.02.17.21251918; this version posted February 22,2021 . The copyright holder for this preprint (which was not certified by peer review) is the author/funder, who has granted medRxiv a license to display the preprint in

226 The differences observed in the glycosylation profile of $\mathrm{T}$ cells across severity, were not

227

228 related to the abundance or activation of $\mathrm{T}$ cell populations, since $\mathrm{CD} 3^{+}, \mathrm{CD}^{+}, \mathrm{CD} 8^{+}$ and $\gamma \delta \mathrm{T}$ cells showed similar frequencies as well as similar levels of PD1 and CD69 expression between the groups, with the exception of lowered $\mathrm{CD}^{+}$population and increased $\mathrm{CD} 9^{+}$within $\mathrm{CD} 8^{+} \mathrm{T}$ cells, in the mild disease group (Supplemental Figure 1A, B and C).

In addition, and since glycosylation is a dynamic process that can change along with disease status, we took advantage of a limited longitudinal follow-up analysis using a single patient, representative of each severity group (asymptomatic, mild, moderate and severe), which revealed that levels of expression of $\beta 1,6-G l c N A c$ and $\alpha 2,6$-sialylation are restored in patients that improved disease severity at day 14 post-diagnosis (Supplemental Figure 1D).

No major differences were observed for other glycan structures such as fucosylation (AAL binding) or mannosylation (GNA binding) in the different $\mathrm{T}$ cell subsets at diagnosis (Supplemental Figure 1A and B).

These results showed that SARS-CoV-2 infected individuals led to an en bloc decreased expression of specific glycan structures such as $B 1,6-$ GlcNAc branched $N$-glycans and $\alpha 2,6$-sialic acid in $\mathrm{T}$ cells, predominately in $\mathrm{CD} 8^{+} \mathrm{T}$ cells and asymptomatic patients. The absence of differences on high mannose structures (GNA binding) or fucose residues on $\mathrm{T}$ cells (AAL binding), support the specificity of the glycan switch. In fact, decreased levels of $\beta 1,6$-branched $N$-glycans in $\mathrm{T}$ cells have been pointed out as a mechanism of TCR threshold regulation, by hampering the TCR complex clustering and lowering the necessary amount of antigen-recognition to signal a cellular response(28). Moreover, surface $\alpha 2,6$-sialylation also regulates $\mathrm{T}$ cell immune response through galectins binding modulation(29-31).

In order to further clarify the underlying mechanism that imposes the changes in the glycosylation profile of circulating $\mathrm{T}$ cells upon SARS-CoV-2 infection, we have performed an in vitro assay, in which PBMCs isolated from healthy individuals were co-cultured with plasma from 4 patients from either each group: non-IF, asymptomatic or moderate disease. Our results showed that $\mathrm{T}$ cells, upon co-culture with plasma from asymptomatic patients displayed a significant decreased expression of $\beta 1,6-G l c N A c$ branched $N$-glycans (Figure 2A) and $\alpha 2,6$-sialylation (Figure 2B), when compared to T 
medRxiv preprint doi: https://doi.org/10.1101/2021.02.17.21251918; this version posted February 22,2021 . The copyright holder for this preprint (which was not certified by peer review) is the author/funder, who has granted medRxiv a license to display the preprint in

258

259

260

261

262

263

264

265

266

267

268

269

270

271

272

273

274

275

276

277

278

279

280

281

282

283

284

285

286

287

288

cells cultured with plasma from non-IF individuals and moderate disease patients. These results suggest the existence a specific serum factor that in asymptomatic patients drives a remarkable drop of complex branched and sialylated glycans structures on T cells. In fact, it is known that asymptomatic patients display a differential serum composition of cytokines and chemokines, when compared to symptomatic $(32,33)$. Moreover, T cell glycosylation is known to be modulated by specific interleukins, namely IL-2 and IL-7 that regulate the transcription of specific Golgi glycosyltransferases(17, 25), which renders the hypothesis that an extracellular factor could be mediating the $\mathrm{T}$ cells glycan switch in a more efficient manner in asymptomatic than symptomatic patients.

\section{Levels of DC-SIGN expression in circulating monocytes predict COVID-19 prognosis}

To gain further insights in the viral-glycan recognition mechanism, we have characterized the expression of specific GBPs expressed by innate immune cells that are known to sense and recognize specific viral glycans, instructing an immune response(34). Regarding the abundance of innate cells, we have observed an increase in the frequency of dendritic cells (DCs) as well as monocytes (Mo) in asymptomatic patients, when compared to Non-IF individuals, and no differences in terms of NK and NK-T cells subsets (Supplemental Figure 1B). Regarding their activation state, analysed by CD86 expression, only monocytes are shown to be activated in asymptomatic and mild disease patients (Supplemental Figure 1C). This is in accordance with previous findings(35).

Specifically, DC-SIGN, a C-type-lectin that recognizes mannose structures, is already known to play a role in the SARS-COV-2 recognition(24), being expressed by monocytes, immature DCs and macrophages. Our results showed that patients from the asymptomatic group displayed higher levels of DC-SIGN expression in monocytes compared moderate disease (Figure 3A), suggesting an increased capacity of asymptomatic patients to sense and recognize the virus.

Taking into consideration the biological relevance of DC-SIGN expression in monocytes as the first sensing mechanism upon SARS-CoV-2 infection, and given the heterogenous expression of DC-SIGN among infected individuals (at diagnosis), (Figure 3A) we next analysed its prognostic value. A longitudinal cohort was used with 
medRxiv preprint doi: https://doi.org/10.1101/2021.02.17.21251918; this version posted February 22,2021 . The copyright holder for this preprint (which was not certified by peer review) is the author/funder, who has granted medRxiv a license to display the preprint in

clinical information in terms of disease progression (development of a poor versus good prognosis at day 14 post-diagnosis, characterized in Supplementary Table 1). Remarkably, the expression levels of DC-SIGN in monocytes were found to be able to stratify patients at diagnosis in terms of their likelihood of developing a good versus a poor disease prognosis with a specificity and sensitivity of $78.9 \%$ and $63.6 \%$, respectively (Figure 3B). The univariate analysis demonstrated that high levels of DCSIGN expression in monocytes at diagnosis increase the odds ratio (OD) associated with the prediction of having a good prognosis, $\mathrm{OD}=6.548 p$-value $=0.011$. In fact, the recognition of the coronaviruses' glycans by innate immune cells was demonstrated to be mediated by DC-SIGN $(23,24)$. An increased expression of this C-type-lectin at the initial days of infection suggests a more efficient viral recognition and subsequent clearance, resulting in a good prognosis of the disease.

\section{Discussion}

Our results demonstrated for the first time that SARS-CoV-2 infection imposes a glycosylation reprogramming of adaptive immune cells suggesting a specific glycan switch of $\mathrm{T}$ cells that may define their ability to successfully deal with infection. We identified a specific glycosylation signature of circulating $\mathrm{T}$ cells that is associated with their activity and function, distinguishing infected patients from non-infected individuals. Our results also suggest that the glycan switch imprinted in circulating $\mathrm{T}$ cells could be mediated by a serum extracellular factor(s), occurring just after SARSCoV-2 infection (Supplemental Figure 2). In fact, previous evidences from others and us demonstrated that the deficiency in branched $\mathrm{N}$-glycan structures on T cells imposes a hyper-reactive phenotype with decreased threshold of $\mathrm{T}$ cell activation and increased $\mathrm{T}$ cell activity $(13,28)$. We herein propose that the immune response against SARS$\mathrm{CoV}-2$ infection appears to be influenced by the glycosylation profile of circulating $\mathrm{T}$ cells which defines their effective functions. In fact, a pronounced deficiency of complex branched and sialylated glycans on $\mathrm{CD}^{+}$and $\gamma \delta \mathrm{T}$ cells were observed in asymptomatic COVID-19 patients. This dynamic and plastic glycoimmune modulation (“Glyco-Immune Alert” mechanism) may constitute a novel mechanism of hostresponse, that contributes to further understand the immunological differences among infected individuals(36). 
medRxiv preprint doi: https://doi.org/10.1101/2021.02.17.21251918; this version posted February 22,2021 . The copyright holder for this preprint (which was not certified by peer review) is the author/funder, who has granted medRxiv a license to display the preprint in

321 Furthermore, we also showed another glycan-based mechanism of host response to

322 SARS-CoV-2 driven by the upregulation of the viral's glycans recognizing receptor

323 DC-SIGN in monocytes, with prognostic application when detected at diagnosis.

324 This study unlocks the identification of a specific glycosignature of $\mathrm{T}$ cells as well as a prognostic biomarker in COVID-19. Further studies are needed to explore the mechanistic impact of the $\mathrm{T}$ cell glycan switch in infection and along disease course. Moreover, it is fundamental to identify the critical serological factor(s) that instructs this T cells glyco-reprogramming, as a potential new biomarker and therapeutic target. Our study was conducted during the first wave of COVID-19 (March-July 2020) having a limitation in terms of sample size, indicating the need to validate these promising observations in larger and well-characterized multicentric cohorts as well as analysing the impact of other SARS-CoV-2 variants in T cells glycan switch.

These new evidences in COVID-19 pave the way to the identification of a specific blood glycosignature able to stratify patients at diagnosis according with their risk to evolve to worsen disease. This will certainly contribute to improve vaccination strategy and patients risk stratification, optimizing an effective allocation and management of health care resources such as ventilators and intensive care facilities.

Acknowledgments: We would like also to thank to all the Portuguese clinicians involved in COVID-19 patients 'care, with a special thanks to those from CHUP and CHVNG that directly or indirectly contributed to this work (Dr. Tiago Teixeira from CHVNG) and to all the patients that accepted to participate in this study. We also acknowledge the nurses and technicians that collaborated in the collection of the samples, especially Nurse Teresa Cruz from CHUP.

Author contributions: IA, MV and SSP designed research. IA, MV, JG, AF, AMD and CSR performed research. SSP contributed new reagents/analytical tools. NS, LM, MAA and RSC provided and characterized clinical samples. IA and MV analysed data. IA, MV and SSP wrote the manuscript with contributions from all authors.

Conflict of interests: The authors declare no competing financial interests. 
medRxiv preprint doi: https://doi.org/10.1101/2021.02.17.21251918; this version posted February 22, 2021. The copyright holder for this preprint (which was not certified by peer review) is the author/funder, who has granted medRxiv a license to display the preprint in

All rights reserved. No reuse allowed without permission.

1. WHO. Dashboard | WHO Coronavirus Disease (COVID-19). .

2. Dong, E., H. Du, and L. Gardner. 2020. An interactive web-based dashboard to track COVID-19 in real time. Lancet. Infect. Dis. 20: 533-534.

3. Wu, Z., and J. M. McGoogan. 2020. Characteristics of and Important Lessons From the Coronavirus Disease 2019 (COVID-19) Outbreak in China: Summary of a Report of 72314 Cases From the Chinese Center for Disease Control and Prevention. JAMA 323: $1239-1242$.

4. Baden, L. R., H. M. El Sahly, B. Essink, K. Kotloff, S. Frey, R. Novak, D. Diemert, S. A. Spector, N. Rouphael, C. B. Creech, J. McGettigan, S. Kehtan, N. Segall, J. Solis, A. Brosz, C. Fierro, H. Schwartz, K. Neuzil, L. Corey, P. Gilbert, H. Janes, D. Follmann, M. Marovich, J. Mascola, L. Polakowski, J. Ledgerwood, B. S. Graham, H. Bennett, R. Pajon, C. Knightly, B. Leav, W. Deng, H. Zhou, S. Han, M. Ivarsson, J. Miller, T. Zaks, and COVE Study Group. 2020. Efficacy and Safety of the mRNA-1273 SARS-CoV-2 Vaccine. N. Engl. J. Med.

5. Polack, F. P., S. J. Thomas, N. Kitchin, J. Absalon, A. Gurtman, S. Lockhart, J. L. Perez, G. Pérez Marc, E. D. Moreira, C. Zerbini, R. Bailey, K. A. Swanson, S. Roychoudhury, K. Koury, P. Li, W. V Kalina, D. Cooper, R. W. Frenck, L. L. Hammitt, Ö. Türeci, H. Nell, A. Schaefer, S. Ünal, D. B. Tresnan, S. Mather, P. R. Dormitzer, U. Şahin, K. U. Jansen, W. C. Gruber, and C4591001 Clinical Trial Group. 2020. Safety and Efficacy of the BNT162b2 mRNA Covid-19 Vaccine. N. Engl. J. Med. 383: 26032615.

6. Guan, W., Z. Ni, Y. Hu, W. Liang, C. Ou, J. He, L. Liu, H. Shan, C. Lei, D. S. C. Hui, B. Du, L. Li, G. Zeng, K.-Y. Yuen, R. Chen, C. Tang, T. Wang, P. Chen, J. Xiang, S. Li, J. Wang, Z. Liang, Y. Peng, L. Wei, Y. Liu, Y. Hu, P. Peng, J. Wang, J. Liu, Z. Chen, G. Li, Z. Zheng, S. Qiu, J. Luo, C. Ye, S. Zhu, and N. Zhong. 2020. Clinical Characteristics of Coronavirus Disease 2019 in China. N. Engl. J. Med. 382: 17081720.

7. Laing, A. G., A. Lorenc, I. del Molino del Barrio, A. Das, M. Fish, L. Monin, M. Muñoz-Ruiz, D. R. McKenzie, T. S. Hayday, I. Francos-Quijorna, S. Kamdar, M. Joseph, D. Davies, R. Davis, A. Jennings, I. Zlatareva, P. Vantourout, Y. Wu, V. Sofra, F. Cano, M. Greco, E. Theodoridis, J. Freedman, S. Gee, J. N. E. Chan, S. Ryan, E. 
medRxiv preprint doi: https://doi.org/10.1101/2021.02.17.21251918; this version posted February 22, 2021. The copyright holder for this preprint (which was not certified by peer review) is the author/funder, who has granted medRxiv a license to display the preprint in All rights reserved. No reuse allowed without permission.

Bugallo-Blanco, P. Peterson, K. Kisand, L. Haljasmägi, L. Chadli, P. Moingeon, L. Martinez, B. Merrick, K. Bisnauthsing, K. Brooks, M. A. A. Ibrahim, J. Mason, F. Lopez Gomez, K. Babalola, S. Abdul-Jawad, J. Cason, C. Mant, J. Seow, C. Graham, K. J. Doores, F. Di Rosa, J. Edgeworth, M. Shankar-Hari, and A. C. Hayday. 2020. A dynamic COVID-19 immune signature includes associations with poor prognosis. Nat. Med. 1-13.

8. Zhou, R., K. K.-W. To, Y.-C. Wong, L. Liu, B. Zhou, X. Li, H. Huang, Y. Mo, T.-Y. Luk, T. T.-K. Lau, P. Yeung, W.-M. Chan, A. K.-L. Wu, K.-C. Lung, O. T.-Y. Tsang, W.-S. Leung, I. F.-N. Hung, K.-Y. Yuen, and Z. Chen. 2020. Acute SARS-CoV-2 Infection Impairs Dendritic Cell and T Cell Responses. Immunity 53: 864-877.

9. Lucas, C., P. Wong, J. Klein, T. B. R. Castro, J. Silva, M. Sundaram, M. K. Ellingson, T. Mao, J. E. Oh, B. Israelow, T. Takahashi, M. Tokuyama, P. Lu, A. Venkataraman, A. Park, S. Mohanty, H. Wang, A. L. Wyllie, C. B. F. Vogels, R. Earnest, S. Lapidus, I. M. Ott, A. J. Moore, M. C. Muenker, J. B. Fournier, M. Campbell, C. D. Odio, A. Casanovas-Massana, R. Herbst, A. C. Shaw, R. Medzhitov, W. L. Schulz, N. D. Grubaugh, C. Dela Cruz, S. Farhadian, A. I. Ko, S. B. Omer, and A. Iwasaki. 2020. Longitudinal analyses reveal immunological misfiring in severe COVID-19. Nature 584: 463-469.

10. Mehta, P., D. F. McAuley, M. Brown, E. Sanchez, R. S. Tattersall, J. J. Manson, and U. HLH Across Speciality Collaboration. 2020. COVID-19: consider cytokine storm syndromes and immunosuppression. Lancet (London, England) 395: 1033-1034.

11. Pereira, M. S., I. Alves, M. Vicente, A. Campar, M. C. Silva, N. A. Padrão, V. Pinto, Â. Fernandes, A. M. Dias, and S. S. Pinho. 2018. Glycans as Key Checkpoints of T Cell Activity and Function. Front. Immunol. 9: 2754.

12. Varki, A., R. D. Cummings, J. D. Esko, P. Stanley, G. W. Hart, M. Aebi, A. G. Darvill, T. Kinoshita, N. H. Packer, J. H. Prestegard, R. L. Schnaar, and P. H. Seeberger. 2015. Essentials of Glycobiology,. Cold Spring Harbor Laboratory Press.

13. Dias, A. M., A. Correia, M. S. Pereira, C. R. Almeida, I. Alves, V. Pinto, T. A. Catarino, N. Mendes, M. Leander, M. T. Oliva-Teles, L. Maia, C. Delerue-Matos, N. Taniguchi, M. Lima, I. Pedroto, R. Marcos-Pinto, P. Lago, C. A. Reis, M. Vilanova, and S. S. Pinho. 2018. Metabolic control of $\mathrm{T}$ cell immune response through glycans in 
medRxiv preprint doi: https://doi.org/10.1101/2021.02.17.21251918; this version posted February 22, 2021. The copyright holder for this preprint (which was not certified by peer review) is the author/funder, who has granted medRxiv a license to display the preprint in

All rights reserved. No reuse allowed without permission.

inflammatory bowel disease. Proc. Natl. Acad. Sci. U. S. A. 115: E4651-E4660.

14. Silva, M. C., Â. Fernandes, M. Oliveira, C. Resende, A. Correia, J. C. De-FreitasJunior, A. Lavelle, J. Andrade-da-Costa, M. Leander, H. Xavier-Ferreira, J. Bessa, C. Pereira, R. M. Henrique, F. Carneiro, M. Dinis-Ribeiro, R. Marcos-Pinto, M. Lima, B. Lepenies, H. Sokol, J. C. Machado, M. Vilanova, and S. S. Pinho. 2020. Glycans as Immune Checkpoints: Removal of Branched N-glycans Enhances Immune Recognition Preventing Cancer Progression. Cancer Immunol. Res. 8: 1407-1425.

15. Ryan, S. O., and B. A. Cobb. 2012. Roles for major histocompatibility complex glycosylation in immune function. Semin. Immunopathol. 34: 425-41.

16. Demetriou, M., M. Granovsky, S. Quaggin, and J. W. Dennis. 2001. Negative regulation of T-cell activation and autoimmunity by Mgat5 N-glycosylation. Nature 409: 733-9.

17. Mkhikian, H., A. Grigorian, C. F. Li, H.-L. Chen, B. Newton, R. W. Zhou, C. Beeton, S. Torossian, G. G. Tatarian, S.-U. Lee, K. Lau, E. Walker, K. A. Siminovitch, K. G. Chandy, Z. Yu, J. W. Dennis, and M. Demetriou. 2011. Genetics and the environment converge to dysregulate $\mathrm{N}$-glycosylation in multiple sclerosis. Nat. Commun. 2: 1-13.

18. Grigorian, A., S. Torossian, and M. Demetriou. 2009. T-cell growth, cell surface organization, and the galectin-glycoprotein lattice. Immunol. Rev. 230: 232-46.

19. Pereira, M. S., C. Durães, T. A. Catarino, J. L. Costa, I. Cleynen, M. Novokmet, J. Krištić, J. Štambuk, N. Conceição-Neto, J. C. Machado, R. Marcos-Pinto, F. Magro, S. Vermeire, G. Lauc, P. Lago, and S. S. Pinho. 2020. Genetic Variants of the MGAT5 Gene Are Functionally Implicated in the Modulation of $\mathrm{T}$ Cells Glycosylation and Plasma IgG Glycome Composition in Ulcerative Colitis. Clin. Transl. Gastroenterol. 11: e00166.

20. Van Breedam, W., S. Pöhlmann, H. W. Favoreel, R. J. de Groot, and H. J. Nauwynck. 2014. Bitter-sweet symphony: glycan-lectin interactions in virus biology. FEMS Microbiol. Rev. 38: 598-632.

21. Watanabe, Y., Z. T. Berndsen, J. Raghwani, G. E. Seabright, J. D. Allen, O. G. Pybus, J. S. McLellan, I. A. Wilson, T. A. Bowden, A. B. Ward, and M. Crispin. 2020. 
medRxiv preprint doi: https://doi.org/10.1101/2021.02.17.21251918; this version posted February 22,2021 . The copyright holder for this preprint (which was not certified by peer review) is the author/funder, who has granted medRxiv a license to display the preprint in perpetuity.

443 Vulnerabilities in coronavirus glycan shields despite extensive glycosylation. Nat. 444 Commun. 11: 1-10.

445 22. Watanabe, Y., J. D. Allen, D. Wrapp, J. S. McLellan, and M. Crispin. 2020. Site446 specific glycan analysis of the SARS-CoV-2 spike. Science 369: 330-333.

447 23. Marzi, A., T. Gramberg, G. Simmons, P. Möller, A. J. Rennekamp, M. Krumbiegel, 448 M. Geier, J. Eisemann, N. Turza, B. Saunier, A. Steinkasserer, S. Becker, P. Bates, H. 449 Hofmann, and S. Pöhlmann. 2004. DC-SIGN and DC-SIGNR interact with the 450 glycoprotein of Marburg virus and the S protein of severe acute respiratory syndrome coronavirus. J. Virol. 78: 12090-5.

452 24. Amraie, R., M. A. Napoleon, W. Yin, J. Berrigan, E. Suder, G. Zhao, J. Olejnik, S. 453 Gummuluru, E. Muhlberger, V. Chitalia, and N. Rahimi. 2020. CD209L/L-SIGN and 454 CD209/DC-SIGN act as receptors for SARS-CoV-2 and are differentially expressed in 455 lung and kidney epithelial and endothelial cells. bioRxiv 2020.06.22.165803.

456 25. Grigorian, A., H. Mkhikian, and M. Demetriou. 2012. Interleukin-2, Interleukin-7, T 457 cell-mediated autoimmunity, and N-glycosylation. Ann. N. Y. Acad. Sci. 1253: 49-57. 26. Dias, A. M., J. Dourado, P. Lago, J. Cabral, R. Marcos-Pinto, P. Salgueiro, C. R. 459 Almeida, S. Carvalho, S. Fonseca, M. Lima, M. Vilanova, M. Dinis-Ribeiro, C. A. Reis, and S. S. Pinho. 2014. Dysregulation of T cell receptor N-glycosylation: a molecular mechanism involved in ulcerative colitis. Hum. Mol. Genet. 23: 2416-27.

462 27. Bagriaçik, E. U., and K. S. Miller. 1999. Cell surface sialic acid and the regulation 463 of immune cell interactions: the neuraminidase effect reconsidered. Glycobiology 9: $267-75$.

28. Demetriou, M., M. Granovsky, S. Quaggin, and J. W. Dennis. 2001. Negative regulation of T-cell activation and autoimmunity by Mgat5 $\mathrm{N}$-glycosylation. Nature 409: 733-739.

29. Pappu, B. P., and P. A. Shrikant. 2004. Alteration of cell surface sialylation regulates antigen-induced naive CD8+ T cell responses. J. Immunol. 173: 275-84. 
medRxiv preprint doi: https://doi.org/10.1101/2021.02.17.21251918; this version posted February 22, 2021. The copyright holder for this preprint (which was not certified by peer review) is the author/funder, who has granted medRxiv a license to display the preprint in

All rights reserved. No reuse allowed without permission.

472 Kedzierska. 2020. Breadth of concomitant immune responses prior to patient recovery:

473 a case report of non-severe COVID-19. Nat. Med. 26: 453-455.

474 31. Matzinger, P. 2002. The danger model: a renewed sense of self. Science 296: 301-5.

475 32. Long, Q.-X., X.-J. Tang, Q.-L. Shi, Q. Li, H.-J. Deng, J. Yuan, J.-L. Hu, W. Xu, Y.

476 Zhang, F.-J. Lv, K. Su, F. Zhang, J. Gong, B. Wu, X.-M. Liu, J.-J. Li, J.-F. Qiu, J. Chen,

477 and A.-L. Huang. 2020. Clinical and immunological assessment of asymptomatic

478 SARS-CoV-2 infections. Nat. Med. 26: 1200-1204.

479 33. Pérez-Cabezas, B., R. Ribeiro, I. Costa, S. Esteves, A. R. Teixeira, T. Reis, R.

480 Monteiro, A. Afonso, V. Pinheiro, M. I. Antunes, M. L. Araújo, J. N. Ribeiro, A.

481 Cordeiro-da-Silva, N. Santarém, and J. Tavares. 2021. IL-2 and IFN- $\gamma$ are biomarkers of

482 SARS-CoV-2 specific cellular response in whole blood stimulation assays. medRxiv $483 \quad 2021.01 .04 .20248897$.

484 34. van Kooyk, Y., and G. A. Rabinovich. 2008. Protein-glycan interactions in the 485 control of innate and adaptive immune responses. Nat. Immunol. 9: 593-601.

486 35. Netea, M. G., E. J. Giamarellos-Bourboulis, J. Domínguez-Andrés, N. Curtis, R. van 487 Crevel, F. L. van de Veerdonk, and M. Bonten. 2020. Trained Immunity: a Tool for 488 Reducing Susceptibility to and the Severity of SARS-CoV-2 Infection. Cell 181: 969489977.

490 36. Luo, M., J. Liu, W. Jiang, S. Yue, H. Liu, and S. Wei. 2020. IL-6 and CD8+ T cell 491 counts combined are an early predictor of in-hospital mortality of patients with COVID492 19. JCI Insight 5. 
medRxiv preprint doi: https://doi.org/10.1101/2021.02.17.21251918; this version posted February 22, 2021. The copyright holder for this preprint (which was not certified by peer review) is the author/funder, who has granted medRxiv a license to display the preprint in All rights reserved. No reuse allowed without permission.

A

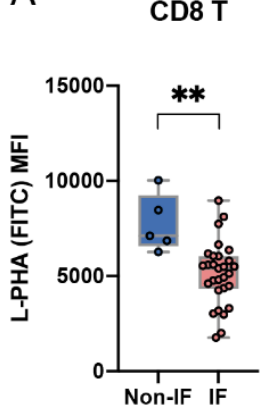

CD4 T

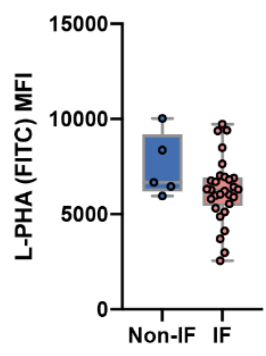

$\gamma \delta \mathbf{T}$

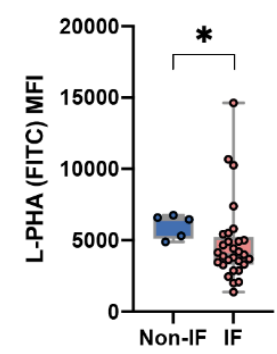

CD8 T

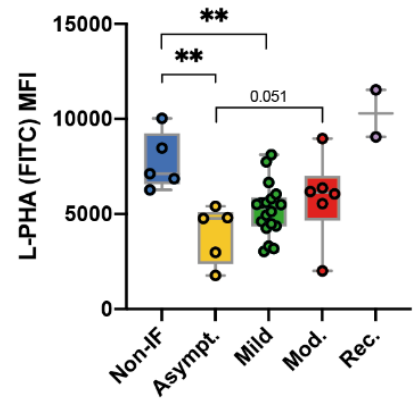

CD4 T

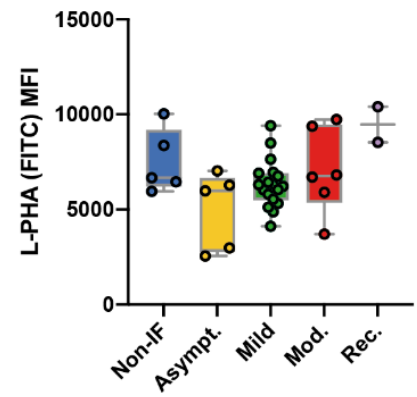

gd T

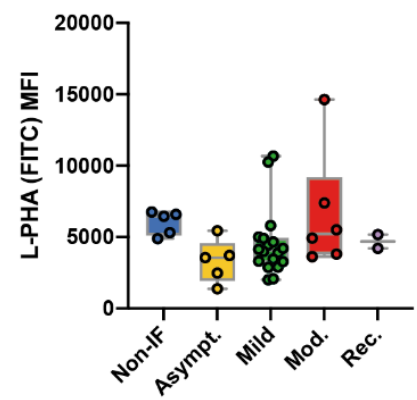

B
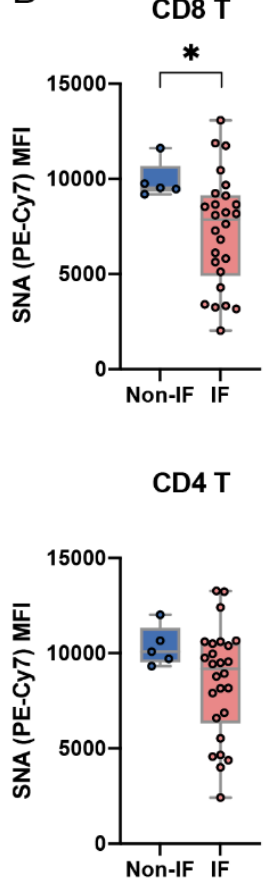

$\gamma \delta \mathbf{T}$

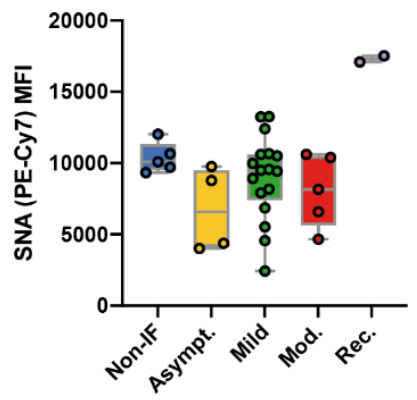

$\gamma \delta \mathrm{T}$

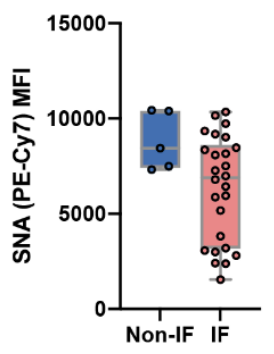

494

Fig.1 - Peripheral $\mathrm{T}$ cell glycoprofile is altered upon SARS-CoV-2 infection at diagnosis. Levels (Mean intensity fluorescence, MFI) of (A) L-PHA lectin binding, detecting $\beta 1,6-$ GlcNAc branched $N$-glycans and (B) SNA lectin binding, detecting a-2,6 sialylation, in $\mathrm{CD}^{+}, \mathrm{CD}^{+}$and $\gamma \delta \mathrm{T}$ cell subsets of non-infected donors (Non-IF; $\mathrm{n}=5$ ) and infected (IF; n=30) patients. Levels of (A) L-PHA and (B) SNA lectin binding for each disease severity group: asymptomatic (Asympt.;n=5), mild ( $\mathrm{n}=18)$, moderate

501 (Mod.; n=6) and recovered (Rec; n=2) Each dot represents one patient. Mann-Whitney t-test was performed to evaluate statistically significance differences between each group-pair. ${ }^{*} p$-value $<0.05, * *<0.005$. 
medRxiv preprint doi: https://doi.org/10.1101/2021.02.17.21251918; this version posted February 22, 2021. The copyright holder for this preprint (which was not certified by peer review) is the author/funder, who has granted medRxiv a license to display the preprint in All rights reserved. No reuse allowed without permission.

A
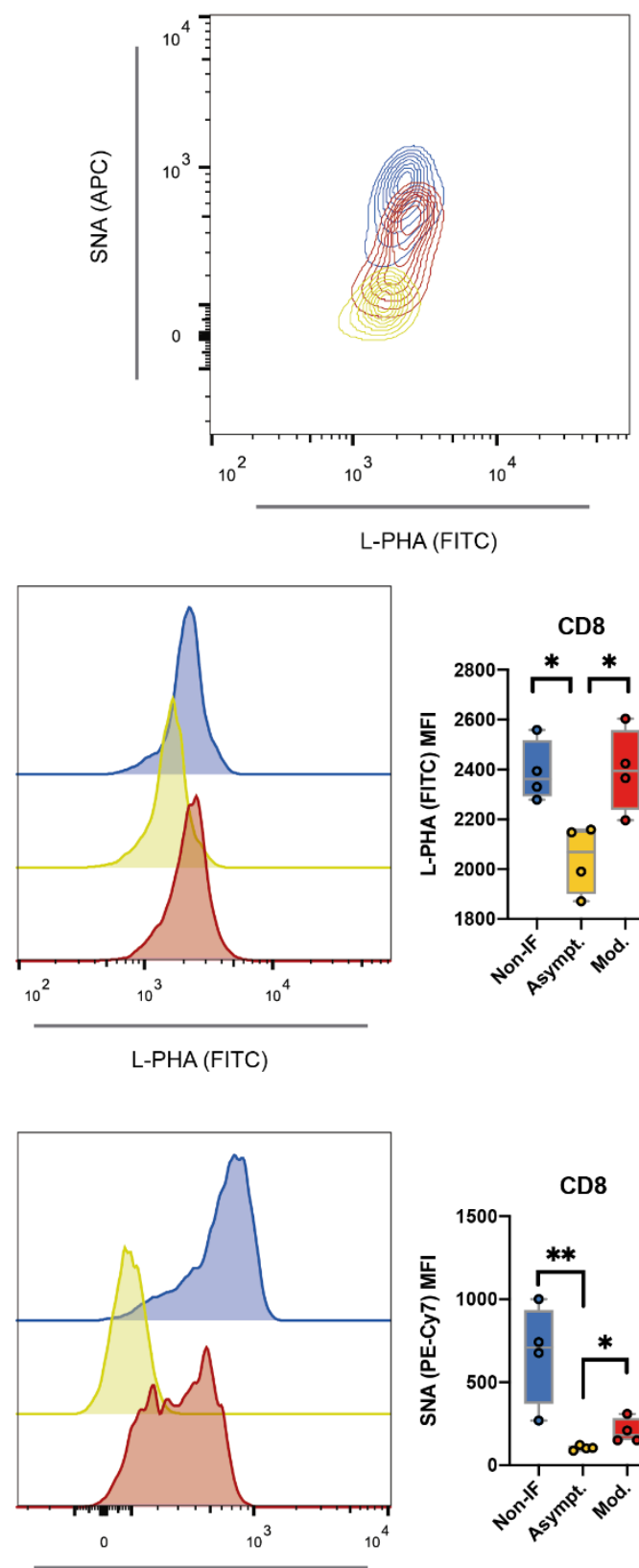

SNA (APC)
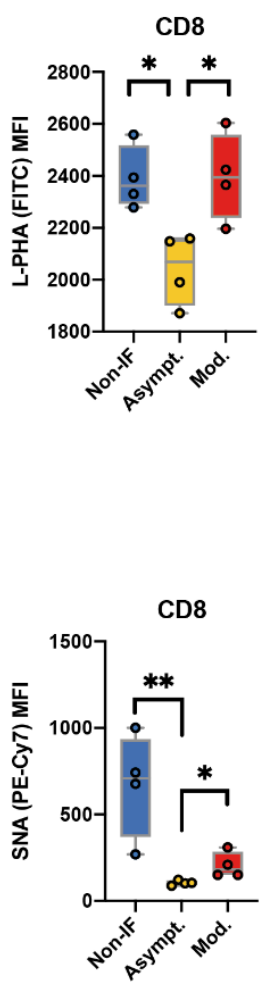

B
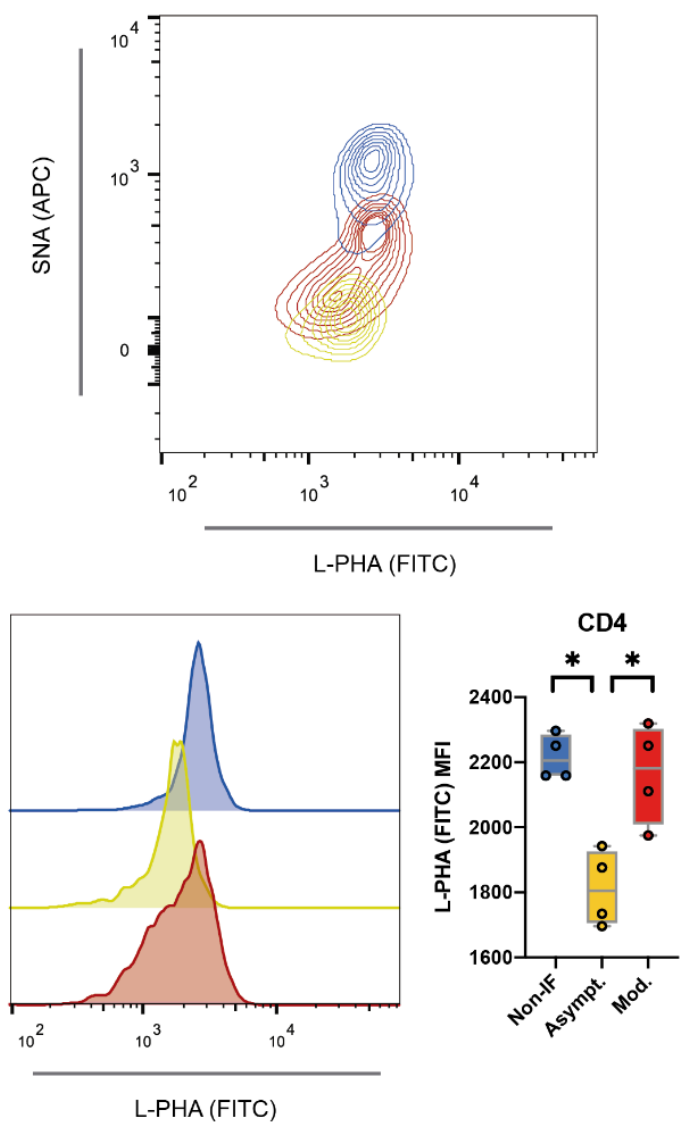

Figure 2 - Patient-derived serum induces a differential $\mathrm{T}$ cell glycosylation comparing
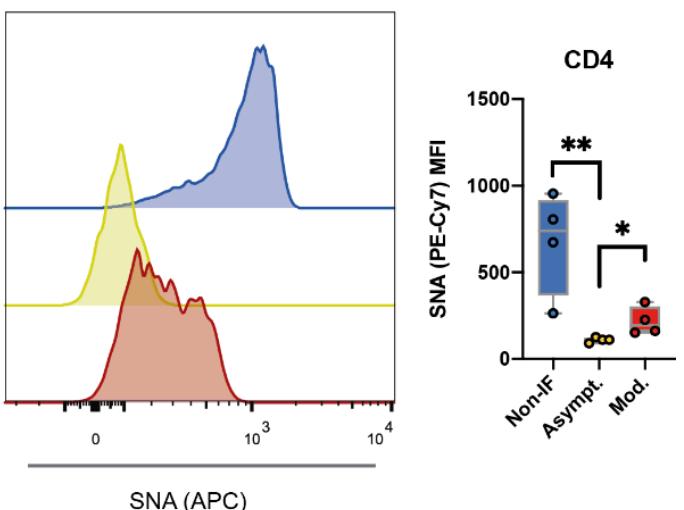
asymptomatic and symptomatic patients (A) L-PHA lectin and (B) SNA lectin binding

507 (MFI) of $\mathrm{CD}^{+}$and $\mathrm{CD}^{+} \mathrm{T}$ cells from a healthy donor, independent of our cohort, 508 incubated for 24-hours with $10 \%$ plasma from 4 patients from each group (Non-IF, 509 asymptomatic or moderate). Each dot represents a subject. Gating strategies for each 510 population are included in Supplemental Figure 1A. Mann-Whitney t-test was 511 performed to evaluate statistically significance differences between each group-pair. * $p$-value $<0.05, * *<0.005$. 
medRxiv preprint doi: https://doi.org/10.1101/2021.02.17.21251918; this version posted February 22, 2021. The copyright holder for this preprint (which was not certified by peer review) is the author/funder, who has granted medRxiv a license to display the preprint in

All rights reserved. No reuse allowed without permission.

A
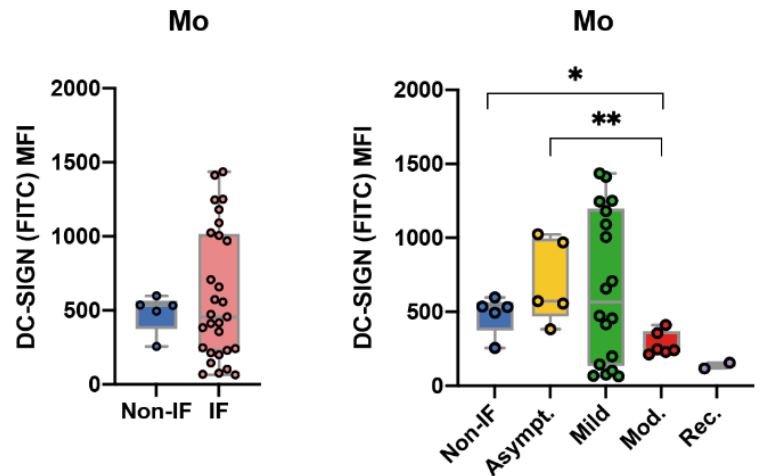

B
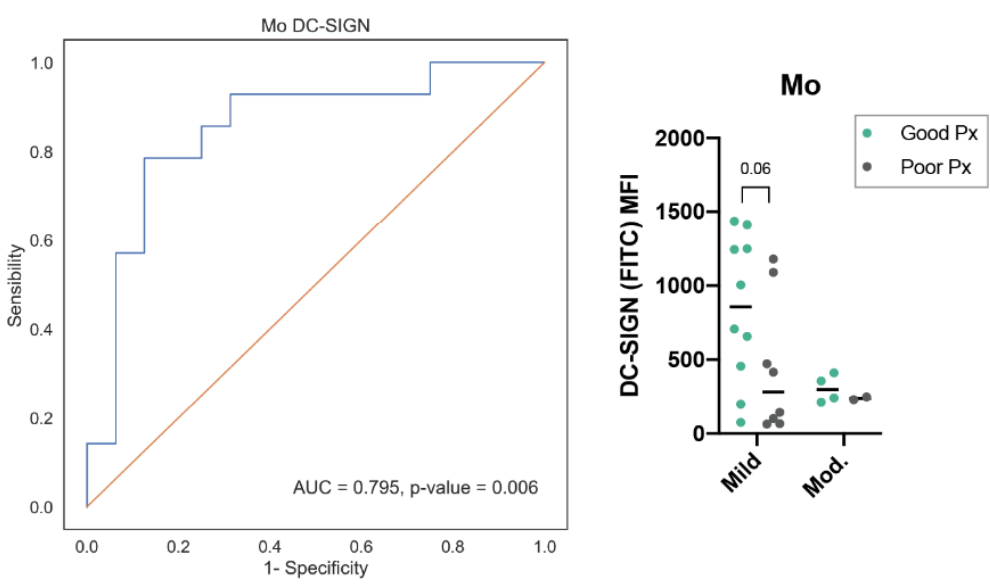

513

514 Fig.3 - DC-SIGN expression in peripheral monocytes as a predictor of good vs. poor

515 prognosis in COVID-19 patients. (A) Levels of DC-SIGN surface expression (MFI) in

516 monocytes (Mo). (B) Receiver operating characteristic (ROC) curve plotted for the DC-

517 SIGN expression levels in monocytes from COVID-19 patients. The distribution of DC-

518 SIGN levels are represented regarding the prognosis, Px, (day 14; good Px in green and

519 poor Px in grey) as well as the severity at diagnosis. Each dot represents one patient

$520 \mathrm{~N}=24$. Gating strategies for each population are included in Supplemental Figure 1A.

521 Mann-Whitney t-test was performed to evaluate statistically significance differences. *

$522 p$-value $<0.05, * *<0.005$, or represented. 